Filol. linguist. port., n. 12(1), p. 105-123, 2010.

\title{
O texto que se lê de autores nacionais
}

\author{
Camila de Paula Moreira* \\ Larissa Gonçalves Forster" \\ Ludmila De Nardi" \\ Ligia Wey Neves Lima* \\ Phablo Roberto Marchis Fachin ${ }^{* * * * x}$
}

RESUMO: Este artigo apresenta amostragem de diferenças encontradas em edições da mesma obra de autores nacionais que levantam dúvidas em relação ao texto de que se valeram as editoras. A diversidade de textos de uma mesma obra provoca a pesquisa da fonte: originais do autor, edição revisada pelo autor, alguma edição alterada por editores, ou ainda acúmulo de erros sobrepostos ao longo da tradição impressa. Limita-se o artigo ao levantamento, pela impossibilidade de avançar nas etapas da pesquisa especializada de cada obra, mas com apoio em bibliografia pertinente, ensaia uma classificação dos problemas encontrados.

palavras-chave: Filologia portuguesa; crítica textual; língua portuguesa; literatura brasileira.

ABSTRACT: This article presents a sample of the differences found in editions from the same literary works written by national writers, which have raised doubts in relation to the original texts used by the publishing houses. The diversity of texts from the same literary work has led us to research the sources: the originals used by the author, editions revised by the author, some editions altered by the editors or even the vast number of errors introduced during the document's printing tradition. The article concentrates on the survey, due to the impossibility of developing a deeper and more specialized research into each literary work. However, with the support of relevant bibliography, it proposes a classification of problems found.

Keywords: Portuguese philology; textual criticism; Portuguese language; Brazilian literature.

Graduação USP. E-mail: camila.moreira@usp.br, larissagf@ig.com.br, lud-_luli@ hotmail.com.

** Graduação USP. E-mail: Bolsista Fapesp. E-mail: ligialima@gmail.com.

*** Doutorando do Programa de Pós-Graduação em Filologia e Língua Portuguesa da Universidade de São Paulo - Bolsista FAPESP. E-mail: phablo@hotmail.com. 


\section{Introdução}

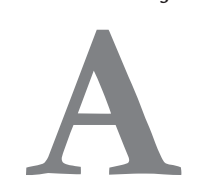

preocupação com o apuro do texto é antiga, remonta à investigação filológica de Alexandria que organizou e cotejou parte dos testemunhos da tradição manuscrita de diversas obras clássicas. Mas é no século XIX que a escola fundada pelo alemão Karl Lachmann consagra a Crítica Textual como ciência responsável pela recuperação e transmissão do patrimônio de uma cultura através da edição e reconstrução de textos, literário, jurídico, histórico etc. (Spina, 1977). Para demonstrar a amplitude do termo Filologia, Cambraia (2005, p.19) aponta a definição de Crítica Textual, como o estudo meticuloso dos documentos, com vistas à restituição de sua genuinidade.

$\mathrm{Na}$ tradição manuscrita medieval, por exemplo, textos com mais de um testemunho podem apresentar alterações pela intervenção do copista durante o processo de transmissão, como a substituição de alguma palavra. Alterações tidas tradicionalmente como erros variam numericamente de acordo com as condições materiais, psicológicas e culturais do copista, sendo transmitidas também à tradição impressa (Blecua, 1983).

No caso de textos modernos, em que teoricamente a tradição manuscrita pode limitar-se aos originais do autor, as alterações vão aparecer na tradição impressa. Há edições de Iracema de José de Alencar, ditas integrais, que, comparadas com outras, apresentam variantes que põem em dúvida a fidedignidade do texto. Em outros casos, como na segunda edição de Livro do Desassossego de Fernando Pessoa, Zenith (2006) reconhece a dificuldade de lidar com os manuscritos do autor e comenta as correções feitas e o procedimento da releitura proporcionado pela retomada dos originais, pelo retorno às fontes, a fim de conferir fidedignidade ao texto, já que reconhece algumas falhas na primeira edição.

A par de informações como essas, assumimos como proposta de trabalho o cotejo de dois testemunhos de uma mesma obra. Buscamos diferenças que tentamos classificar. Autores como Gregório de Matos, José de Alencar e Machado de Assis propiciaram textos que selecionamos para cotejo, sabendo que os problemas são bem diversos. De Gregório de Matos, por exemplo, não se tem, por enquanto, nenhum testemunho que possa ser considerado autógrafo, e a variedade de apógrafos deixa em aberto a hipótese de haver texto a ele atribuído que pode não ser de sua autoria. Se com os outros autores esse fato não ocorre, os problemas esbarram com a possibilidade de o autor ter intervindo em alguma edição, que seja por acaso a última em vida dele.

O corpus selecionado permite perceber que os textos disponíveis chegam a apresentar diferenças relevantes e comprometedoras da fidedig- 
nidade, a ponto de instalar-se a dúvida de qual seria o original do autor nesta e naquela passagem: o autor escreveu isso ou aquilo? Há obras que poderiam alimentar a hipótese de duas tradições, uma ao lado outra mais curta, ou de outra em que tal trecho ou tais cenas não aparecem. O público leitor, apenas ocasionalmente, toma conhecimento de parte do problema, e a tradição impressa avança intrépida multiplicando edições com problemas sobrepostos.

Apresentam-se os critérios utilizados para a classificação das diferenças, de acordo com Blecua (1983); em seguida, faz-se aplicação desses critérios nas passagens da amostragem dos pontos divergentes entre os testemunhos das obras estudadas, nas edições em questão. Cada uma das categorias está acompanhada de exemplos das obras selecionadas pelos alunos. Segue anexa tabela com o total de ocorrências distribuídas em três colunas: nome da obra e do autor, trecho da edição A e trecho da edição B. Por fim, constam os nomes dos alunos do curso de Filologia Portuguesa que realizaram os trabalhos de cotejo.

\section{Critérios de classificação das diferenças encontradas}

Em ambas as tradições de uma obra, seja manuscrita, seja impressa, o confronto entre testemunhos é a única forma de constatar se tal texto é, ou não, genuíno. Para tanto, a Crítica Textual tem princípios capazes de restituir ao texto a forma mais próxima da última vontade do autor, senão a própria vontade do autor.

Esse procedimento exige a recensão de todos os testemunhos de determinada obra, ou seja, a sua tradição direta, e outros tipos de texto que estejam relacionados a ela, como traduções, citações, entre outros, isto é, a sua tradição indireta. Após essa etapa, compara-se o que se selecionou diretamente em busca de pontos que apresentam divergências. Nessa altura, já é possível determinar o grau de relação entre eles, verificar como se deu o seu processo de transmissão e qual o caminho a ser percorrido para reconstituir o texto em sua forma genuína. Como diz Cambraia (2005, p. 135), "terminadas a localização e a coleta das fontes, pode-se passar a uma subfase bastante árdua: a da colação (lat. collatio), etapa em que se comparam os diversos testemunhos de um texto para se localizarem lugares-críticos", pontos do texto em que há divergência.

Esse trabalho demanda do crítico metodologia e conhecimento da matéria, associado ao domínio de informações codicológicas, paleográficas, 
literárias, históricas e lingüísticas, umas mais outras menos úteis, conforme o caso, mas algumas sempre imprescindíveis. Há edições críticas de determinadas obras que, de tão complexas, levam uma vida para serem concretizadas. Como exemplo, pode-se citar O Livro de José de Arimatéia, estudado há muitos anos por pesquisadores de testemunhos de várias línguas e variada procedência e, ainda hoje, sem um texto estabelecido criticamente. A esse respeito, Toledo Neto (2007, p.347) afirma o seguinte:

\footnotetext{
Tomando-se como possível ponto de referência a edição integral da obra, que data de finais da década de sessenta do século passado, pode-se afirmar que, desde aquela época até hoje, ampliou-se muito a sua compreensão, embora muito ainda haja por fazer diante das variadas questões que se encontram em aberto.
}

Pelas razões mencionadas, entre os objetivos dos trabalhos que compõem o corpus deste artigo, não estava a realização de edições críticas das obras dos autores escolhidos, mas apenas o levantamento de pontos divergentes entre os testemunhos coletados, dois por obra. Tarefa essa denominada Colação pela Crítica Textual.

Em geral, a comparação é feita com base num testemunho considerado mais completo e em melhores condições, chamado testemunho de colação (Cambraia, 2005, p. 135). Seria o que mais se aproximasse do original, de acordo com os conhecimentos do crítico. As divergências encontradas, portanto, são classificadas em relação às formas presentes nesse texto. Tradicionalmente, tudo que difere do testemunho de colação é considerado erro, ou seja, formas não-genuínas incorporadas à obra no seu processo de transmissão.

Por não ter em mãos toda a tradição direta das obras, por não ser possível definir o testemunho de cotejo, este trabalho apresenta tão-somente divergências, sem a preocupação de entrar em seu mérito, pois não haveria possibilidade de distinguir quais delas seriam genuínas.

A busca por variantes se baseou na tipologia proposta por Blecua (1983, p.19-20), para quem os quatro tipos de erros possíveis são: por adição (adiectio), omissão (detractatio), alteração (transmutatio) e substituição (immutatio). Optou-se pela junção dos dois primeiros para a exposição do corpus, pois as diferenças descritas aqui podem ser tanto omissão quanto adição, já que não há o testemunho de cotejo como base para distingui-los.

Os trechos utilizados para exemplificar cada tipo de variante não puderam ser classificados entre significativos e não-significativos como 
descrito por Cambraia, pois não seria possível tal análise tendo como base apenas o material disponível. Assim, os trechos foram separados seguindo o critério de mudança de sentido.

(...) é preciso que esse erro seja tão particular e idiossincrático que não possa ter sido cometido simultânea e independentemente por dois copistas. Sua condição de erro não pode ser óbvia, pois, em sendo, os copistas poderiam intervir conjecturalmente e, dependendo da obviedade do erro, poderiam acabar por fazer modificações que resultassem no restabelecimento da própria forma genuína, sem a terem visto. (Cambraia, 2005, p.136)

\section{Divergências entre os testemunhos}

\subsection{Adição e omissão}

Segundo Blecua (1983), a adição ocorre quando há o acréscimo ou repetição de letra, sílaba, palavra ou frase. Já a omissão, quando há a supressão desses elementos. A incidência de ambas as variantes está relacionada a fatores do próprio texto, como a proximidade de palavras iguais ou similares, favorecendo acréscimos ou supressões. Fatores externos ligados à atenção também podem influir na ocorrência das variantes, devido ao salto dado no texto pelo copista que o retoma a partir de uma palavra posterior, igual a que acabara de copiar.

Dentre as ocorrências apontadas nos trabalhos pelos alunos do curso de Filologia, há adição ou omissão de letra, palavra, frase, pontuação e acentuação, não se atendo somente às mencionadas por Blecua.

\subsubsection{Pontuação}

Entre as variantes, o maior número de ocorrências é a de pontuação, cuja adição ou omissão apresentou mudanças significativas em contexto de orações subordinadas adjetivas. De todo modo, representam corrupções em relação ao original.

\begin{tabular}{|c|c|c|}
\hline & Edição A & Edição B \\
\hline Iracema, José de Alencar & $\begin{array}{l}\text { Ergueu ella os olhos e viu entre } \\
\text { as folhas da palmeira sua linda } \\
\text { jandaia, que batia as azas e } \\
\text { arrufava as pennas com o } \\
\text { prazerde vel-a. }\end{array}$ & $\begin{array}{l}\text { Ergueu ela os olhos e viu entre as } \\
\text { folhas da palmeira sua linda jandaia, } \\
\text { que batia as asas, e arrufava as penas } \\
\text { com o prazer de vê-la. }\end{array}$ \\
\hline $\begin{array}{l}\text { "A cada canto um grande } \\
\text { conselheiro", Gregório de } \\
\text { Matos }\end{array}$ & $\begin{array}{l}\text { Estupendas usuras nos } \\
\text { mercados, / Todos os que não } \\
\text { furtam muito pobres: / E eis } \\
\text { aqui a cidade da Bahia. }\end{array}$ & $\begin{array}{l}\text { Estupendas usuras nos mercados, } \\
\text { Todos, os que não furtam, muito } \\
\text { pobres / E eis aqui a cidade da Bahia. }\end{array}$ \\
\hline
\end{tabular}


110 MOREIRA, Camila de Paula; FORSTER, Larissa Gonçalves et al.

\subsubsection{Acentuação}

Há poucos casos de variantes quanto à acentuação. As ocorrências identificadas são referentes à presença ou não de acento circunflexo, grave e agudo, interferindo, neste último caso, expressivamente no sentido da frase.

\begin{tabular}{|c|c|c|}
\hline & Edição A & \begin{tabular}{|c|} 
Edição B \\
\end{tabular} \\
\hline $\begin{array}{c}\text { Dom Casmurro, Machado de } \\
\text { Assis }\end{array}$ & $\begin{array}{l}\text { - "Vou para Petrópolis, Dom } \\
\text { Casmurro; a casa e a mesma da } \\
\text { Renânia; vê se deixas essa } \\
\text { caverna do Engenho Novo, e } \\
\text { vai lá passar uns quinze dias } \\
\text { comigo". }\end{array}$ & $\begin{array}{l}\text { - "Vou para Petrópolis, Dom } \\
\text { Casmurro; a casa é a mesma da } \\
\text { Renânia; vê se deixas essa caverna do } \\
\text { Engenho Novo, e vai lá passar uns } \\
\text { quinze dias comigo". }\end{array}$ \\
\hline $\begin{array}{l}\text { "A cada canto um grande } \\
\text { conselheiro", Gregório de } \\
\text { Matos }\end{array}$ & $\begin{array}{l}\text { Para a levar a Praça, e ao } \\
\text { Terreiro. }\end{array}$ & Para o levar à Praça e ao terreiro \\
\hline
\end{tabular}

\subsubsection{Palavras}

A incidência de variantes de palavras pode causar mudança de sentido de acordo com o distanciamento entre o teor semântico das ocorrências.

\begin{tabular}{|c|l|l|}
\hline & \multicolumn{1}{|c|}{ Edição A } & \multicolumn{1}{|c|}{ Edição B } \\
\hline \multirow{3}{*}{ Senhora, José de Alencar } & $\begin{array}{l}\text { A menina não se importa de } \\
\text { chegar até aos duzentos e } \\
\text { aposto que se for preciso vai } \\
\text { por aí fora, que isso de mulher, } \\
\text { o dinheiro faz-lhe cócegas. }\end{array}$ & $\begin{array}{l}\text { A menina não se importa de chegar } \\
\text { até duzentos mil cruzeiros e } \\
\text { fora, que isso de mulher, o dinheiro } \\
\text { faz-lhe cócegas. }\end{array}$ \\
\hline Iracema, José de Alencar & $\begin{array}{l}\text { Abriram-se os braços do } \\
\text { guerreiro e seus lábios; o nome } \\
\text { da virgem ressoou docemente. }\end{array}$ & $\begin{array}{l}\text { Abriram-se os braços do guerreiro } \\
\text { adormecido e seus lábios; o nome da } \\
\text { virgem ressoou docemente. }\end{array}$ \\
\hline
\end{tabular}

\subsubsection{Frases}

A adição ou omissão de frase ocorre no meio do período ou entre parágrafos, sempre precedido de pontuação.

\begin{tabular}{|c|l|l|}
\hline & \multicolumn{1}{|c|}{ Edição A } & \multicolumn{1}{|c|}{ Edição B } \\
\hline $\begin{array}{c}\text { A mão e a luva, Machado de } \\
\text { Assis }\end{array}$ & $\begin{array}{l}\text { O silencio não era completo; } \\
\text { no aposento, porém, o unico } \\
\text { rumor era dos botins de } \\
\text { Estevam na palhinha do chão. }\end{array}$ & $\begin{array}{l}\text { O silêncio não era completo; ouvia- } \\
\text { se o rodar de carros que passavam } \\
\text { fora; no aposento, porém, o único } \\
\text { rumor era dos botins de Estêvão na } \\
\text { palhinha do chão. }\end{array}$ \\
\hline $\begin{array}{c}\text { "Dentes negros e cabelos } \\
\text { azuis", Lima Barreto }\end{array}$ & $\begin{array}{l}\text { Iniciadas na rua, nossas relações } \\
\text { se estreitaram dia dia. }\end{array}$ & $\begin{array}{l}\text { Iniciadas na rua, nos ligeiros } \\
\text { encontros dos cafés, as nossas } \\
\text { relações se estreitaram dia a dia. }\end{array}$ \\
\hline
\end{tabular}




\section{2. alteração}

O conceito de alteração em crítica textual não se restringe a qualquer tipo de modificação como o nome possa inicialmente sugerir. Segundo Blecua (1983), alteração é uma inversão, podendo variar desde a de palavras até aquela de frases ou parágrafos.

\subsubsection{Entre ênclise e próclise}

Foram observados somente dois casos com esse tipo de inversão. No primeiro, na edição A pode ser observada a utilização do pronome obliquo átono $a$ (próclise na forma la) na função de objeto direto de deixar; já na edição $B$, o pronome tem seu equivalente na ênclise. No segundo caso, nota-se o pronome reflexivo se como uma ênclise na edição A e como uma próclise na edição B. Ambas as inversões não revelam qualquer interferência no aspecto semântico da sentença ou do texto.

\begin{tabular}{|c|l|l|}
\hline & Edição A & Edição B \\
\hline \multirow{3}{*}{ Iracema, José de Alencar } & $\begin{array}{l}\text { O estrangeiro não quer levar } \\
\text { consigo a tristeza da terra } \\
\text { hospedeira, nem deixá-la no }\end{array}$ & $\begin{array}{l}\text { a tristeza da terra hospedeira, nem a } \\
\text { deixar no coração de Iracema! }\end{array}$ \\
\cline { 2 - 3 } & $\begin{array}{l}\text { Iracema afastara-se opressa e e } \\
\text { suspirosa. }\end{array}$ & $\begin{array}{l}\text { Iracema se afastara opressa e } \\
\text { suspirosa. }\end{array}$ \\
\hline
\end{tabular}

\subsubsection{Entre palavras}

No corpus, a inversão entre palavras não causa variação de significado, apenas muda o escopo, como pode ser observado entre as palavras bebas e nelas nas edições A e B de Ubirajara. Em "Um Sansão de caramelo" de Gregório de Matos ocorre situação semelhante: na edição A, a ação recebe maior ênfase, visto que o verbo tomar, tomou, antecede o 'agente'; já na edição B, o 'agente', burro, antecede a ação.

\begin{tabular}{|c|l|l|}
\hline & Edição A & Edição B \\
\hline Ubirajara, José de Alencar & $\begin{array}{l}\text { Sua boca, que ainda não } \\
\text { provaste, Jandira a encherá de } \\
\text { amor para que bebas nela seu } \\
\text { contentamento. }\end{array}$ & $\begin{array}{l}\text { Sua boca, que ainda não provaste, } \\
\text { nela bebas seu contentamento. } \\
\text { nela a enchera de amor para que }\end{array}$ \\
\hline $\begin{array}{c}\text { "Um Sansão de caramelo", } \\
\text { Gregório de Matos }\end{array}$ & $\begin{array}{l}\text { tomou de um burro a a a } \\
\text { queixada, }\end{array}$ & de um burro tomou a queixada, \\
\hline
\end{tabular}

3.2.3. Alteração dupla

Neste único caso, observa-se o par Betica e aplica, mantendo a rima. $\mathrm{Na}$ edição A, Betica está no final do primeiro verso e aplica no final do 
segundo; na edição B, tem-se o contrário: aplica no final do primeiro verso e Betica no final do segundo. A questão semântica desse excerto não será explorada neste tópico, visto que, além do par já mencionado, há muitas outras variantes, principalmente de substituição.

\begin{tabular}{|c|l|l|}
\hline & \multicolumn{1}{|c|}{ Edição A } & \multicolumn{1}{c|}{ Edição B } \\
\hline $\begin{array}{c}\text { "Um Sansão de caramelo", } \\
\text { Gregório de Matos }\end{array}$ & $\begin{array}{l}\text { que se torna a ver Betica/ e as } \\
\text { colunas se lhe aplica,/ que há } \\
\text { de lançá-la por terra. }\end{array}$ & $\begin{array}{l}\text { que se arrima, e aplica/ às colunas } \\
\text { de Betica,/ há de dar com ela em } \\
\text { terra. }\end{array}$ \\
\hline
\end{tabular}

\subsubsection{Alteração mista}

Em alguns casos, há simultaneamente alteração e substituição; em outros, alteração e adição.

\begin{tabular}{|c|l|l|}
\hline & \multicolumn{1}{|c|}{ Edição A } & \multicolumn{1}{|c|}{ Edição B } \\
\hline $\begin{array}{c}\text { "Um calção de pindoba”, } \\
\text { Gregório de Matos }\end{array}$ & De Paiaiá virou-se em Abaeté. & de arecuná se tornou em abaité. \\
\hline $\begin{array}{c}\text { "Um Sansão de caramelo", } \\
\text { Gregório de Matos }\end{array}$ & não nos bofes da cadeia, & nos bofes, não da cadeia, \\
\hline Iracema, José de Alencar & $\begin{array}{l}\text { Vendo Martim a virgem unida } \\
\text { ao seu coração, cuidou que o } \\
\text { sonho continuava; cerrou os } \\
\text { olhos para torná-los a abrir. }\end{array}$ & $\begin{array}{l}\text { Martim, vendo a virgem unida ao seu } \\
\text { coração, cuidou que o sonho } \\
\text { continuava; cerrou os olhos para } \\
\text { torná-los a abrir. }\end{array}$ \\
\hline
\end{tabular}

\subsection{Substituição}

O fenômeno nomeado substituição abrange grande parte das diferenças encontradas nas obras escolhidas para análise. Segundo Blecua (1983), trata-se da substituição de letras, sílabas, palavras ou até mesmo frases inteiras - acidental ou propositalmente. Uma das ocorrências mais freqüentes é a substituição de uma palavra por um sinônimo. Também bastante comum é a substituição por outra palavra de significado completamente diferente, mas de grafia similar.

Destaca-se o número de diferenças nos poemas de Gregório de Matos, e a gravidade das diferenças entre as edições: nas alterações de frases inteiras, o sentido original dos versos se perde, e em cada versão há uma interpretação completamente diferente da outra - o que compromete o estudo da obra. 


\subsubsection{Substituição de palavras}

\subsubsection{Sinonímia}

Quando uma palavra ou frase é substituída por outra de sentido igual ou semelhante.

\begin{tabular}{|c|l|l|}
\hline & \multicolumn{1}{|c|}{ Edição A } & \multicolumn{1}{|c|}{ Edição B } \\
\hline Ubirajara, José de Alencar & $\begin{array}{l}\text { quando começou a dança } \\
\text { guerreira que durou até perto } \\
\text { da alvorada. }\end{array}$ & $\begin{array}{l}\text { quando começou a dança guerreira } \\
\text { que durou ate omper da alvorada. }\end{array}$ \\
\hline Iracema, José de Alencar & $\begin{array}{l}\text { o mal era sonho e ilusão, que da } \\
\text { virgem não possuía senão a a } \\
\text { imagem. }\end{array}$ & $\begin{array}{l}\text { o mal era sonho e ilusão, que da } \\
\text { virgem ele não possuía mais que a } \\
\text { imagem. }\end{array}$ \\
\hline
\end{tabular}

\subsubsection{Grafia semelhante ${ }^{1}$}

Ocorre quando uma palavra é substituída por outra de grafia semelhante. Nesse caso, a mudança no sentido é freqüente, afetando a análise da obra.

\begin{tabular}{|c|c|c|}
\hline & Edição A & Edição B \\
\hline \multirow[t]{2}{*}{ Iracema, José de Alencar } & $\begin{array}{l}\text { Era assim que eu brincava, há } \\
\text { quantos anos, em outro sítio, } \\
\text { não mui distante do seu. }\end{array}$ & $\begin{array}{l}\text { Era assim que eu brincava, há quatro } \\
\text { anos, em outro sítio, não muito } \\
\text { distante do seu. }\end{array}$ \\
\hline & $\begin{array}{l}\text { Percorra suas páginas para } \\
\text { desenfastiar o espírito das } \\
\text { coisas graves que o trazem } \\
\text { ocupado. }\end{array}$ & $\begin{array}{llr}\begin{array}{l}\text { Percorra suas páginas } \\
\text { desenfastiar o espírito das }\end{array} & \text { causas } \\
\text { graves que o trazem ocupado. } & \end{array}$ \\
\hline \multirow{2}{*}{$\begin{array}{l}\text { "Um calção de pindoba a } \\
\text { meia porra", Gregório de } \\
\text { Matos }\end{array}$} & Um calção de pindoba a meia & Um calção de pindoba a meia zorra \\
\hline & $\begin{array}{l}\text { sem mais lei que a do gosto, } \\
\text { quando berra, }\end{array}$ & $\begin{array}{l}\text { Sem mais Leis, que as do gosto, } \\
\text { quando erra, }\end{array}$ \\
\hline $\begin{array}{c}\text { Noite da taverna, Álvares de } \\
\text { Azevedo }\end{array}$ & $\begin{array}{l}\text { A nós frontes queimadas pelo } \\
\text { mormaço do sol da vida, a nós } \\
\text { sobre cuja cabeça a velhice } \\
\text { regelou os cabelos, essas } \\
\text { crenças frias? }\end{array}$ & $\begin{array}{l}\text { A nós frontes queimadas pelo } \\
\text { mormaço do sol da vida, a nós sobre } \\
\text { cuja cabeça a velhice regelou os } \\
\text { cabelos, essas crianças frias! }\end{array}$ \\
\hline
\end{tabular}

\subsubsection{Substituição com adição}

Em alguns casos, a substituição ocorrida por grafia semelhante vem acompanhada por adição.

\begin{tabular}{|c|c|c|}
\hline & Edição A & Edição B \\
\hline $\begin{array}{c}\text { “A uns olhos de viu } \\
\text { rendido”, Gregório de } \\
\text { Matos }\end{array}$ & Arpão de ouro, arpão vencido: & arpões de outro arpão vencido: \\
\hline
\end{tabular}

1 É interessante notar que a maior parte dos exemplos se concentra na substituição por grafia semelhante. 


\section{MOREIRA, Camila de Paula; FORSTER, Larissa Gonçalves et al.}

3.3.1.4. Atração de uma palavra igual no mesmo período

Ocorre quando uma palavra é substituída por outra que está no mesmo período - a própria proximidade entre as palavras favorece este tipo de substituição.

\begin{tabular}{|c|c|c|}
\hline & Edição A & Edição B \\
\hline $\begin{array}{c}\text { Dom Casmurro, Machado de } \\
\text { Assis }\end{array}$ & $\begin{array}{l}\text { Os amigos que me restam são } \\
\text { de data recente; todos os } \\
\text { antigos foram estudar a } \\
\text { geologia dos campos-santos. }\end{array}$ & $\begin{array}{l}\text { Os amigos que me restam são da data } \\
\text { recente; todos os amigos foram } \\
\text { estudar a geologia dos campos-santos. }\end{array}$ \\
\hline
\end{tabular}

\subsubsection{Substituição de frases inteiras}

Este tipo de substituição, na realidade, é uma junção de vários outros tipos, acarretando mudanças drásticas na frase. Nos exemplos abaixo, há adição, omissão, alteração e substituição.

\begin{tabular}{|c|c|c|}
\hline & Edição A & Edição B \\
\hline \multirow[t]{2}{*}{$\begin{array}{l}\text { "Um Sansão de caramelo", } \\
\text { Gregório de Matos }\end{array}$} & $\begin{array}{l}\text { porque afirma cada qual / } \\
\text { entre alvoroço, e sussurro, / } \\
\text { quem livrou dos pés do } \\
\text { burro, / mal morrerá do }\end{array}$ & $\begin{array}{l}\text { antes temeu cada qual, / que o } \\
\text { Sansão de alcomonia / a lanças } \\
\text { matar podia / mais que o outro co } \\
\text { queixal. }\end{array}$ \\
\hline & $\begin{array}{l}\text { que se torna a ver Betica, / e } \\
\text { as colunas se lhe aplica, / que } \\
\text { há de lançá-la por terra. }\end{array}$ & $\begin{array}{l}\text { que se se arrima, e aplica / às colunas } \\
\text { de Betica, / há de dar com ela em } \\
\text { terra. }\end{array}$ \\
\hline
\end{tabular}

\subsubsection{Sem justificativa gráfica e de sentido}

O exemplo abaixo possui substituição sem natureza definida: não há como supor, com base nas definições dadas por Blecua, a razão de tal substituição.

\begin{tabular}{|c|l|l|}
\hline & \multicolumn{1}{|c|}{ Edição A } & \multicolumn{1}{|c|}{ Edição B } \\
\hline $\begin{array}{c}\text { "Um calção de pindoba a } \\
\text { meia porra", Gregório de } \\
\text { Matos }\end{array}$ & $\begin{array}{l}\text { Alarve sem razão, bruto sem } \\
\text { fé, }\end{array}$ & Animal sem razão, bruto sem fé, \\
\hline \hline
\end{tabular}

\subsubsection{Substituição de pontuação}

Trata-se de substituição mais específica do que as anteriores: a de pontuação. Apesar de não ser descrita por Blecua (1983), é interessante observar a abundância de diferentes pontuações em edições da mesma obra, podendo causar divergência na interpretação.

\begin{tabular}{|c|l||l|}
\hline & \multicolumn{1}{|c||}{ Edição A } & \multicolumn{1}{|c|}{ Edição B } \\
\hline $\begin{array}{c}\text { Noite da taverna, Álvares de } \\
\text { Azevedo }\end{array}$ & A nós os sonhos do & A nós os sonhos do espiritualismo! \\
\cline { 2 - 3 } & $\begin{array}{l}\text { - Blasfêmia! e não crês em } \\
\text { mais nada! }\end{array}$ & $\begin{array}{l}\text { - Blasfêmia - e não crês em mais } \\
\text { nada: }\end{array}$ \\
\hline
\end{tabular}




\section{Conclusão}

$\mathrm{Na}$ execução dos textos manuscritos, os copistas antigos podiam decifrar mal o original copiado, cometer erros por distração, por cansaço, até por deliberação pessoal, bem como lacunas e lapsos de toda ordem; outras vezes, podiam extrapolar o modelo copiado, inserindo neles passagens por sua conta ou transcritas de outras cópias também defeituosas (Spina, 1977, p.87). O cotejo de duas edições da mesma obra demonstra que problemas semelhantes podem ocorrer também com textos impressos. Diferente dos textos manuscritos, em que a transmissão de tais modificações se dava de forma lenta e gradual, tal qual o processo de cópia, a corrupção da obra impressa é amplamente divulgada em razão de tiragens em série por meio mecânico.

$\mathrm{Na}$ nossa literatura, os autores consagrados são reeditados muitas vezes, mas lamentavelmente nem sempre com o devido cuidado. A atitude descomprometida frente ao processo de transmissão dessas obras, constatada neste artigo pela amostragem de diferenças entre os testemunhos, comprova a necessidade de edições críticas, visto que, somente assim, os textos poderão ser reconstituídos em sua forma genuína.

\section{Bibliografia}

BLECUA, A. (1983) Manual de crítica textual. Madrid: Castalia.

CAMBRAIA, C. N. (2005) Introdução à crítica textual. São Paulo: Martins Fontes.

MADRUGA, E. de F. As modificações operadas no texto de A Bagaceira. In: II Encontro de Edição Crítica e Crítica Genética: Eclosão do Manuscrito. São Paulo: FFLCH/USP/CNPq. Sem data.

SPAGGIARI, B.; PERUGI, M. (2004) Fundamentos da crítica textual. Rio de Janeiro: Lucerna. SPINA, Segismundo. (1977) Introdução à edótica. São Paulo: Cultrix/Edusp.

TOLEDO NETO, S. de A. (2007) O Livro de José de Arimatéia: comentário sobre questões atuais. Veredas, Revista da Associação Internacional de Lusitanistas, 8, p. 34760. 
116 MOREIRA, Camila de Paula; FORSTER, Larissa Gonçalves et al.

ANEXO 1: Tabela com as divergências entre os testemunhos. $\mathrm{Na}$ primeira coluna, o título da obra e do autor, na segunda e na terceira, os trechos das edições utilizadas.

\section{Adição ou omissão}

\section{Pontuação}

\begin{tabular}{|c|c|c|}
\hline Título da obra/ Autor & Edição A & Edição B \\
\hline $\begin{array}{c}\text { Noite na taverna, Alvares } \\
\text { de Azevedo }\end{array}$ & $\begin{array}{l}\text { - Archibald! deveras que é um } \\
\text { sonho tudo isso! }\end{array}$ & $\begin{array}{l}\text { - Archibald! deveras, que é um sonho } \\
\text { tudo isso! }\end{array}$ \\
\hline \multirow{5}{*}{$\begin{array}{c}\text { "Um calção de pindoba a } \\
\text { meia porra", Gregório de } \\
\text { Matos }\end{array}$} & $\begin{array}{l}\text { Um calção de pindoba a meia } \\
\text { porra, }\end{array}$ & Um calção de pindoba a meia zorra \\
\hline & senão a mãe, a pedra lhe aplicara & $\begin{array}{l}\begin{array}{l}\text { Senão a Mãe, que a pedra the } \\
\text { aplicara, }\end{array} \\
\end{array}$ \\
\hline & $\begin{array}{l}\text { sem mais lei que a do gosto, } \\
\text { quando berra, }\end{array}$ & $\begin{array}{l}\text { Sem mais Leis, que as do gosto, } \\
\text { quando erra, }\end{array}$ \\
\hline & $\begin{array}{l}\text { Não sei como acabou, nem em } \\
\text { que guerra; }\end{array}$ & $\begin{array}{l}\text { Não sei, onde acabou, ou em que } \\
\text { guerra, }\end{array}$ \\
\hline & só sei que do Adão de Marapé & Só sei, que deste Adão de Massapé, \\
\hline \multirow{2}{*}{$\begin{array}{l}\text { "A Mulata", Melo Morais } \\
\text { Filho }\end{array}$} & Me assenta o troço de cassa & Me assenta o torço de cassa, \\
\hline & E eu posso dizer ufana & E eu posso dizer ufana, \\
\hline $\begin{array}{c}\text { "Dentes negros e cabelos } \\
\text { azuis", } \\
\text { Lima Barreto } \\
\end{array}$ & $\begin{array}{l}\text { Era dos mais velhos o } \\
\text { conhecimento que eu mantinha } \\
\text { com esse rapaz. }\end{array}$ & $\begin{array}{l}\text { Era dos mais velhos, o conhecimento } \\
\text { que eu mantinha com êsse rapaz. }\end{array}$ \\
\hline \multirow{7}{*}{$\begin{array}{c}\text { "A cada canto um grande } \\
\text { conselheiro", Gregório de } \\
\text { Matos }\end{array}$} & $\begin{array}{l}\text { A cada canto um grande } \\
\text { conselheiro }\end{array}$ & A cada canto um grande conselheiro, \\
\hline & $\begin{array}{l}\text { Que nos quer governar a cabana } \\
\text { e vinha; }\end{array}$ & $\begin{array}{l}\text { Que nos quer governar a cabana, e } \\
\text { vinha, }\end{array}$ \\
\hline & $\begin{array}{l}\text { Em cada porta um bem freqüente } \\
\text { olheiro }\end{array}$ & $\begin{array}{l}\begin{array}{l}\text { Em cada porta um freqüentado } \\
\text { olheiro, }\end{array} \\
\end{array}$ \\
\hline & $\begin{array}{l}\text { Que a vida do vizinho e da } \\
\text { vizinha }\end{array}$ & Que a vida do vizinho, e da vizinha \\
\hline & $\begin{array}{l}\text { Pesquisa, escuta, espreita e } \\
\text { esquadrinha, }\end{array}$ & \begin{tabular}{|lll}
$\begin{array}{l}\text { Pesquisa, escuta, espreita, e } \\
\text { esquadrinha, }\end{array}$ & e \\
\end{tabular} \\
\hline & Para o levar à Praça e ao terreiro & Para a levar a Praça, e ao Terreiro. \\
\hline & $\begin{array}{l}\text { Todos os que não furtam muito } \\
\text { pobres: }\end{array}$ & $\begin{array}{l}\text { Todos, os que não furtam, muito } \\
\text { pobres, }\end{array}$ \\
\hline \multirow{3}{*}{ Iracema, José de Alencar } & $\begin{array}{l}\text { Uma vez, que a formosa filha de } \\
\text { Araken, se lamentava á beira da } \\
\text { lagôa da Macejana, uma voz } \\
\text { estridente gritou seu nome do alto } \\
\text { da carnaúba: }\end{array}$ & $\begin{array}{l}\text { Uma vez que a formosa filha de } \\
\text { Araquém, se lamentava à beira da } \\
\text { lagoa da Mecejana, uma voz estridente } \\
\text { gritou seu nome do alto da carnaúba: }\end{array}$ \\
\hline & $\begin{array}{l}\text { Ergueu ella os olhos e viu entre as } \\
\text { folhas da palmeira sua linda } \\
\text { jandaia, que batia as azas e } \\
\text { arrufava as pennas com o prazer } \\
\text { de vel-a. }\end{array}$ & $\begin{array}{l}\text { Ergueu ela os olhos e viu entre as } \\
\text { folhas da palmeira sua linda jandaia, } \\
\text { que batia as asas, e arrufava as penas } \\
\text { com o prazer de vê-la. }\end{array}$ \\
\hline & $\begin{array}{l}\text { Alongando faceiro o collo, com o } \\
\text { negro bico, alisou-lhe os cabellos } \\
\text { e beliscou-lhe a bocca mimosa e } \\
\text { vermelha como a pitanga. }\end{array}$ & $\begin{array}{l}\text { Alongando fagueira o colo, com o } \\
\text { negro bico alisou-lhe os cabelos } \mathrm{e} \\
\text { beliscou a boca mimosa e vermelha } \\
\text { como a pitanga. }\end{array}$ \\
\hline \multirow{3}{*}{ Ubirajara, José de Alencar } & $\begin{array}{l}\text { Três vêzes cessaram a luta e de } \\
\text { novo a travaram. }\end{array}$ & $\begin{array}{l}\text { Três vezes cessaram a luta, e de novo } \\
\text { a travaram. }\end{array}$ \\
\hline & $\begin{array}{l}\text { Mas, afinal, se convenceram de } \\
\text { que nenhum derrubaria o outro. }\end{array}$ & $\begin{array}{l}\text { Mas afinal se convenceram que } \\
\text { nenhum derrubaria o outro. }\end{array}$ \\
\hline & $\begin{array}{l}\text { Os anciãos sentados no longo } \\
\text { jirau contemplam taciturnos a } \\
\text { geração de guerreiros... }\end{array}$ & $\begin{array}{l}\text { Os anciões, sentados no longo jirau, } \\
\text { contemplam taciturnos a geração de } \\
\text { guerreiros... }\end{array}$ \\
\hline
\end{tabular}




\begin{tabular}{|c|c|c|}
\hline \multirow{9}{*}{$\begin{array}{l}\text { "Virgem morta", Álvares } \\
\text { de Azevedo }\end{array}$} & $\begin{array}{l}\text { Lá onde geme a brisa do } \\
\text { crepúsculo }\end{array}$ & $\begin{array}{l}\text { E, quando geme a brisa do } \\
\text { crepúsculo, }\end{array}$ \\
\hline & $\begin{array}{l}\text { Vagueie em torno, de saudosas } \\
\text { virgens }\end{array}$ & \begin{tabular}{|l}
$\begin{array}{l}\text { Vagueie em torno, de saudosas } \\
\text { virgens, }\end{array}$ \\
\end{tabular} \\
\hline & $\begin{array}{l}\text { E, entre cânticos de amor e de } \\
\text { saudade, }\end{array}$ & Nos cânticos de amor e de saudade \\
\hline & No túmulo da virgem derramá-la. & No túmulo da virgem, derramá-la. \\
\hline & $\begin{array}{l}\text { Que importa que ela durma } \\
\text { descorada }\end{array}$ & $\begin{array}{l}\text { Que importa que ela durma } \\
\text { descorada, }\end{array}$ \\
\hline & $\begin{array}{l}\text { Quero a delícia que o amor } \\
\text { sonhava }\end{array}$ & Quero a delícia que o amor sonhava, \\
\hline & $\begin{array}{l}\mathrm{Na} \text { minha fronte riu de ti, } \\
\text { passando, }\end{array}$ & Na minha fronte riu de ti passando \\
\hline & $\begin{array}{l}\text { Bem cedo, ao menos, eu serei } \\
\text { contigo }\end{array}$ & Bem cedo ao menos eu serei contigo \\
\hline & $\begin{array}{l}\text { Nas noites junto ao mar e no } \\
\text { silêncio, }\end{array}$ & $\begin{array}{l}\text { Nas noites junto ao mar, e no } \\
\text { silêncio, }\end{array}$ \\
\hline \multirow{4}{*}{$\begin{array}{c}\text { "Um Sanção de } \\
\text { caramelo", Gregório de } \\
\text { Matos }\end{array}$} & por firmar-se na estacada & por firmar-se na estacada, \\
\hline & outros dizem, que era sua: & (que outros dizem que era a sua) \\
\hline & porque afirma cada qual & antes temeu cada qual, \\
\hline & jura Sansão, brama, e berra, & jura Sansão, brama e berra" \\
\hline \multirow{5}{*}{$\begin{array}{l}\text { “A uns olhos se viu } \\
\text { rendido”, Gregório de } \\
\text { Matos }\end{array}$} & “desfez o céu para tinta," & "Desfez o Ceo para tinta" \\
\hline & arpões de outro arpão vencido: & Arpão de ouro, arpão vencido: \\
\hline & guiado de seus antolhos & Guiado de seos antolhos, \\
\hline & puseram de morte cor & Pozerão de morte cor, \\
\hline & olhos que vencem a Amor & Olhos, que vencem o amor: \\
\hline
\end{tabular}

\begin{tabular}{|c|c|c|}
\hline Título da obra/ Autor & $\begin{array}{c}\text { Edição A } \\
\end{array}$ & \begin{tabular}{|c|} 
Edição B \\
\end{tabular} \\
\hline \multirow[t]{2}{*}{$\begin{array}{l}\text { Noite na taverna, Álvares } \\
\text { de Azevedo }\end{array}$} & $\begin{array}{l}\text {-Estás ébrio, Johann! O ateísmo é } \\
\text { a insânia como o idealismo } \\
\text { místico de Schelling, o panteísmo } \\
\text { de Spinoza o judeu, e o crente de } \\
\text { Malebranche nos seus sonhos da } \\
\text { visão em Deus. }\end{array}$ & $\begin{array}{l}\text {-Estás ébrio, Johann! O ateísmo é a } \\
\text { insânia como o idealismo místico de } \\
\text { Schelling, o panteísmo de Spinoza - } \\
\text { o judeu, e o histerismo crente de } \\
\text { Malebranche nos seus sonhos da } \\
\text { visão em Deus. }\end{array}$ \\
\hline & $\begin{array}{l}\text { A fronte da mulher pendeu - e } \\
\text { sua mão passou na garganta dele. } \\
\text { - Um soluço rouco e sufocado } \\
\text { ofegou daí. }\end{array}$ & $\begin{array}{l}\text { A fronte da mulher pendeu e sua } \\
\text { mão pousou na garganta dele. Um } \\
\text { soluço rouco e sufocado ofegou daí. }\end{array}$ \\
\hline $\begin{array}{l}\text { “A Mulata”, Melo Morais } \\
\text { Filho }\end{array}$ & Adeus, meu yôyô, adeus... & - Adeus, meu yôyô, adeus... \\
\hline $\begin{array}{c}\text { Dom Casmurro, Machado } \\
\text { de Assis }\end{array}$ & $\begin{array}{l}\text { Meu caro Dom Casmurro, não } \\
\text { cuide que o dispenso do teatro } \\
\text { amanhã; venha e dormirá aqui na } \\
\text { cidade; dou-lhe camarote, dou-lhe } \\
\text { chá, dou-lhe cama; só não lhe dou } \\
\text { moça. }\end{array}$ & $\begin{array}{l}\text { - Meu caro Dom Casmurro, não } \\
\text { cuide que o dispenso do teatro } \\
\text { amanhã; venha e dormirá aqui na } \\
\text { cidade; dou-lhe camarote, dou-lhe } \\
\text { chá, dou-lhe cama; só não the dou } \\
\text { moça. }\end{array}$ \\
\hline Iracema, José de Alencar & Iracema!... Iracema!... & - Iracema!... Iracema!... \\
\hline
\end{tabular}

\begin{tabular}{|c|c|c|}
\hline Título da Obra/ Autor & Edição A & Edição B \\
\hline Iracema, José de Alencar & Meu amigo & Meu amigo. \\
\hline \multirow{3}{*}{$\begin{array}{l}\text { "Virgem morta", Álvares } \\
\text { de Azevedo }\end{array}$} & $\begin{array}{l}\text { Inda virgem do alento dos } \\
\text { amores... }\end{array}$ & Inda virgem do alento dos amores!... \\
\hline & $\begin{array}{l}\text { Lábio de morte murmurou - } \hat{\mathrm{E}} \\
\text { tarde! }\end{array}$ & $\begin{array}{l}\text { Lábio de morte murmurou: - } \hat{\mathrm{E}} \\
\text { tarde! }\end{array}$ \\
\hline & $\begin{array}{l}\text { Sentir-me abandonado e } \\
\text { moribundo! }\end{array}$ & $\begin{array}{l}\text { Sentir-me abandonado e } \\
\text { moribundo!?... }\end{array}$ \\
\hline $\begin{array}{l}\text { "A uns olhos se viu } \\
\text { rendido", Gregório de } \\
\text { Matos }\end{array}$ & olhos que vencem a Amor & Olhos, que vencem o amor: \\
\hline
\end{tabular}


118 MOREIRA, Camila de Paula; FORSTER, Larissa Gonçalves et al.

\section{Acentuação}

\begin{tabular}{|c|l|l|}
\hline Título da obra/ Autor & \multicolumn{1}{|c|}{ Edição A } & \multicolumn{1}{|c|}{ Edição B } \\
\hline $\begin{array}{c}\text { Dom Casmurro, Machado } \\
\text { de Assis }\end{array}$ & $\begin{array}{l}\text { - Vou para Petrópolis, Dom } \\
\text { Casmurro; a casa e a mesma da } \\
\text { Renânia; vê se deixas essa caverna } \\
\text { do Engenho Novo, e vai lá passar } \\
\text { uns quinze dias comigo. }\end{array}$ & $\begin{array}{l}\text { Vou para Petrópolis, Dom } \\
\text { Casmurro; a casa é a mesma da } \\
\text { Renânia; vê se deixas essa caverna do } \\
\text { Engenho Novo, e vai lá passar uns } \\
\text { quinze dias comigo. }\end{array}$ \\
\hline $\begin{array}{c}\text { A mão e a luva, Machado } \\
\text { de Assis }\end{array}$ & $\begin{array}{l}\text { O silencio não era completo; no } \\
\text { aposento, porém, o unico rumor } \\
\text { era dos botins de Estevam na } \\
\text { palhinha do chão. }\end{array}$ & $\begin{array}{l}\text { O silêncio não era completo; ouvia-se } \\
\text { o rodar de carros que passavam fora; } \\
\text { no aposento, porém, o único rumor } \\
\text { era dos botins de Estêvão na palhinha } \\
\text { do chão. }\end{array}$ \\
\hline $\begin{array}{c}\text { “A cada canto um grande } \\
\text { conselheiro", Gregório de } \\
\text { Matos }\end{array}$ & Para a levar a Praça, e ao Terreiro. & Para o levar à Praça e ao terreiro \\
\hline $\begin{array}{c}\text { Ubirajara, José de Alencar } \\
\text { A mão e a luva, Machado } \\
\text { de Assis }\end{array}$ & $\begin{array}{l}\text { Minha fama corre as tabas e tu já } \\
\text { deves conhecer... }\end{array}$ & $\begin{array}{l}\text { Minha fama corre às tabas e tu já } \\
\text { deves conhecer... }\end{array}$ \\
\hline $\begin{array}{l}\text { Oposento, norém, o unico rumor nor } \\
\text { era dos botins de Estevam na } \\
\text { palhinha do chão. }\end{array}$ & $\begin{array}{l}\text { O silêncio não era completo; ouvia- } \\
\text { se o rodar de carros que passavam } \\
\text { fora; no aposento, porém, o único } \\
\text { rumor era dos botins de Estêvão na } \\
\text { palhinha do chão. }\end{array}$ \\
\hline
\end{tabular}

\section{Frases}

\begin{tabular}{|c|c|c|}
\hline Título da Obra/ Autor & Edição A & Edição B \\
\hline $\begin{array}{c}\text { A mão e a lwva, Machado } \\
\text { de Assis }\end{array}$ & $\begin{array}{l}\text { O silencio não era completo; no } \\
\text { aposento, porém, o unico rumor } \\
\text { era dos botins de Estevam na } \\
\text { palhinha do chão. }\end{array}$ & $\begin{array}{l}\text { O silêncio não era completo; ouvia- } \\
\text { se o rodar de carros que passavam } \\
\text { fora; no aposento, porém, o único } \\
\text { rumor era dos botins de Estêvão na } \\
\text { palhinha do chão. }\end{array}$ \\
\hline $\begin{array}{l}\text { "Dentes negros e cabelos } \\
\text { azuis", Lima Barreto }\end{array}$ & $\begin{array}{l}\text { Iniciadas na rua, as nossas } \\
\text { relações se estreitaram dia a dia. }\end{array}$ & $\begin{array}{l}\text { Iniciadas na rua, nos ligeiros } \\
\text { encontros dos cafés, as nossas } \\
\text { relaçôes se estreitaram dia a dia. }\end{array}$ \\
\hline \multirow{3}{*}{ Iracema, José de Alencar } & $\begin{array}{l}\text { Martim lho arrebatou das mãos, e } \\
\text { libou as gotas do verde e amargo } \\
\text { licor. }\end{array}$ & $\begin{array}{l}\text { Martim lho arrebatou das mãos, e } \\
\text { libou as poucas gotas do verde e } \\
\text { amargo licor. Não tardou que a rede } \\
\text { recebesse seu corpo desfalecido. }\end{array}$ \\
\hline & $\begin{array}{l}\text { Quando veio pela manhã, ainda } \\
\text { achou Iracema ali debruçada, qual } \\
\text { borboleta que dormiu no seio do } \\
\text { formoso cacto. Em seu lindo } \\
\text { semblante acendia o pejo vivos } \\
\text { rubores; e como entre os arrebóis } \\
\text { da manhã cintila o primeiro raio } \\
\text { de sol, em suas faces incendidas } \\
\text { rutilavam o primeiro sorriso da } \\
\text { esposa, aurora de fruído amor. } \\
\text { A jandaia fugira ao romper } \\
\text { d'alva e para não tornar mais à } \\
\text { cabana. }\end{array}$ & $\begin{array}{l}\text { Quando veio pela manhã, ainda achou } \\
\text { Iracema ali debruçada, qual borboleta } \\
\text { que dormiu no seio do formoso cacto. } \\
\text { Em seu lindo semblante acendia o } \\
\text { pejo vivos rubores; e como entre os } \\
\text { arrebóis da manhã cintila o primeiro } \\
\text { raio de sol, em suas faces incendidas } \\
\text { rutilavam o primeiro sorriso da } \\
\text { esposa, aurora de fruído amor. } \\
\text { Martim, vendo a virgem unida ao seu } \\
\text { coração, cuidou que o sonho } \\
\text { continuava; cerrou os olhos para } \\
\text { torná-los a abrir. }\end{array}$ \\
\hline & $\begin{array}{l}\text { Vendo Martim a virgem unida ao } \\
\text { seu coração, cuidou que o sonho } \\
\text { continuava; cerrou os olhos para } \\
\text { torná-los a abrir. }\end{array}$ & \\
\hline
\end{tabular}




\section{Palavra}

\begin{tabular}{|c|c|c|}
\hline Título da obra/ Autor & $\begin{array}{c}\text { Edição } \mathbf{A} \\
\end{array}$ & \begin{tabular}{|c|} 
Edição B \\
\end{tabular} \\
\hline \multirow{2}{*}{$\begin{array}{c}\text { "Um calção de pindoba a } \\
\text { meia porra", Gregório de } \\
\text { Matos }\end{array}$} & $\begin{array}{l}\text { Furado o beiço, sem temor que } \\
\text { morra, }\end{array}$ & $\begin{array}{l}\text { Furado o beiço, e sem temor que } \\
\text { morra, }\end{array}$ \\
\hline & senão a mãe, a pedra lhe aplicara & Senão a Mãe, que a pedra the aplicara, \\
\hline $\begin{array}{l}\text { "Virgem morta", Álvares } \\
\text { de Azevedo }\end{array}$ & Mais poesia do arrebol transpira; & E mais poesia o arrebol transpira... \\
\hline \multirow{3}{*}{$\begin{array}{c}\text { "Um Sanção de } \\
\text { caramelo", Gregório de } \\
\text { Matos }\end{array}$} & outros dizem, que era sua: & (que outros dizem que era a sua) \\
\hline & que há de lançá-la por terra. & há de dar com ela em terra. \\
\hline & ali o cabelo lhe dão, & se o cabelo ali the dão, \\
\hline $\begin{array}{l}\text { Dom Casmurro, Machado } \\
\text { de Assis }\end{array}$ & Pois é coisa de lágrimas? & Pois isto é cousa de lágrimas? \\
\hline \multirow[t]{2}{*}{ Iracema, José de Alencar } & $\begin{array}{l}\text { A jandaia, abrindo as asas, } \\
\text { esvoaçou-lhe em torno e pousou } \\
\text { no ombro. }\end{array}$ & $\begin{array}{l}\text { A jandaia, abrindo as azas, esvoaçou- } \\
\text { lhe em torno e pousou-lhe no } \\
\text { hombro. }\end{array}$ \\
\hline & $\begin{array}{l}\text { Alongando fagueira o colo, com o } \\
\text { negro bico alisou-lhe os cabelos e } \\
\text { beliscou a boca mimosa e } \\
\text { vermelha como a pitanga. }\end{array}$ & $\begin{array}{l}\text { Alongando faceiro o collo, com o } \\
\text { negro bico, alisou-lhe os cabellos e } \\
\text { beliscou-lhe a bocca mimosa e } \\
\text { vermelha como a pitanga. }\end{array}$ \\
\hline Ubirajara, José de Alencar & $\begin{array}{l}\text { Mas afinal se convenceram que } \\
\text { nenhum derrubaria o outro. }\end{array}$ & $\begin{array}{l}\text { Mas, afinal, se convenceram de que } \\
\text { nenhum derrubaria o outro. }\end{array}$ \\
\hline Iracema, José de Alencar & $\begin{array}{l}\text { Ėste livro vai naturalmente } \\
\text { encontrá-lo no seu pitoresco sítio } \\
\text { da várzea, no doce lar, que povoa } \\
\text { a numerosa prole, alegria e } \\
\text { esperança do casal. }\end{array}$ & $\begin{array}{l}\text { Este livro o vai naturalmente } \\
\text { encontrar em seu pitoresco sítio da } \\
\text { várzea, no doce lar, a que povoa a } \\
\text { numerosa prole, alegria e esperança } \\
\text { do casal. } \\
\end{array}$ \\
\hline $\begin{array}{l}\text { "A cada canto um grande } \\
\text { conselheiro", Gregório de } \\
\text { Matos }\end{array}$ & $\begin{array}{l}\text { Em cada porta um freqüentado } \\
\text { olheiro, }\end{array}$ & $\begin{array}{l}\text { Em cada porta um bem freqüente } \\
\text { olheiro }\end{array}$ \\
\hline \multirow[b]{2}{*}{ Senhora, José de Alencar } & $\begin{array}{l}\text { - Não se recusam cem contos de } \\
\text { réis, pensava ele, sem razão sólida, } \\
\text { uma razão prática. }\end{array}$ & $\begin{array}{l}\text { - Não se recusam cem mil cruzeiros, } \\
\text { pensava êle, sem uma razão sólida, } \\
\text { uma razão prática. }\end{array}$ \\
\hline & $\begin{array}{l}\text { A menina não se importa de } \\
\text { chegar até aos duzentos e aposto } \\
\text { que se for preciso vai por aí fora, } \\
\text { que isso de mulher, o dinheiro } \\
\text { faz-lhe cócegas. }\end{array}$ & $\begin{array}{l}\text { A menina não se importa de chegar } \\
\text { até aos duzentos mil cruzeiros e } \\
\text { aposto que se for preciso vai por aí } \\
\text { fora, que isso de mulher, o dinheiro } \\
\text { faz-lhe cócegas. }\end{array}$ \\
\hline \multirow[t]{2}{*}{ Iracema, José de Alencar } & $\begin{array}{l}\text { Martim lho arrebatou das mãos, e } \\
\text { libou as gotas do verde e amargo } \\
\text { licor. }\end{array}$ & $\begin{array}{l}\text { Martim tho arrebatou das mãos, e } \\
\text { libou as poucas gotas do verde e } \\
\text { amargo licor. }\end{array}$ \\
\hline & $\begin{array}{l}\text { Abriram-se os braços do guerreiro } \\
\text { adormecido e seus lábios; o } \\
\text { nome da virgem ressoou } \\
\text { docemente. }\end{array}$ & $\begin{array}{l}\text { Abriram-se os braços do guerreiro e } \\
\text { seus lábios; o nome da virgem ressoou } \\
\text { docemente. }\end{array}$ \\
\hline \multirow[b]{2}{*}{$\begin{array}{l}\text { Noite na taverna, Álvares } \\
\text { de Azevedo }\end{array}$} & Os copos caíram na mesa. & Os copos caíram vazios na mesa. \\
\hline & $\begin{array}{l}\text {-Estás ébrio, Johann! O ateísmo é } \\
\text { a insânia como o idealismo } \\
\text { místico de Schelling, o panteísmo } \\
\text { de Spinoza o judeu, e o crente de } \\
\text { Malebranche nos seus sonhos da } \\
\text { visão em Deus. }\end{array}$ & $\begin{array}{l}\text {-Estás ébrio, Johann! O ateísmo é a } \\
\text { insânia como o idealismo místico de } \\
\text { Schelling, o panteísmo de Spinoza - o } \\
\text { judeu, e o histerismo crente de } \\
\text { Malebranche no seus sonhos da visão } \\
\text { em Deus. }\end{array}$ \\
\hline
\end{tabular}


120 MOREIRA, Camila de Paula; FORSTER, Larissa Gonçalves et al.

\begin{tabular}{|c|c|c|}
\hline T'́tule d o obra / Autor & & Edicão B \\
\hline \multirow{3}{*}{ Iracema, José de Alencar } & $\begin{array}{l}\text { Edição A } \\
\text { O estrangeiro não quer levar } \\
\text { consigo a tristeza da terra } \\
\text { hospedeira, nem deixá-la no }\end{array}$ & $\begin{array}{l}\text { E estrangeiro não quer levar consigo } \\
\text { a tristeza da terra hospedeira, nem a } \\
\text { deixar no coração de Iracema! }\end{array}$ \\
\hline & $\begin{array}{l}\text { Iracema afastara-se opressa e } \\
\text { suspirosa. }\end{array}$ & $\begin{array}{lllll}\begin{array}{l}\text { Iracema } \\
\text { suspirosa. }\end{array} & \text { afastara } & \text { opressa } & \text { e } \\
\text { sula }\end{array}$ \\
\hline & $\begin{array}{l}\text { Vendo Martim a virgem unida } \\
\text { ao seu coração, cuidou que o } \\
\text { sonho continuava; cerrou os } \\
\text { ollhos para torná-los a abrir. }\end{array}$ & 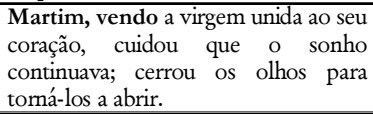 \\
\hline \multirow{3}{*}{$\begin{array}{c}\text { "Um Sansão de caramelo", } \\
\text { Gregório de Matos }\end{array}$} & Não nos bofes da cadeia, & Nos bofes, não da cadeia, \\
\hline & $\begin{array}{l}\text { que se torna a ver Betica/ e as } \\
\text { colunas se lhe aplica,/ que há } \\
\text { de lançá-la por terra. }\end{array}$ & $\begin{array}{l}\text { que se se arrima, e aplica/ às colunas } \\
\text { de Betica,/ há de dar com ela em } \\
\text { terra. }\end{array}$ \\
\hline & $\begin{array}{l}\begin{array}{l}\text { tomou de } \\
\text { queixada, }\end{array} \\
\end{array}$ & de um burro tomou a queixada, \\
\hline Ubirajara, José de Alencar & $\begin{array}{l}\text { Sua boca, que ainda não } \\
\text { provaste, Jandira a encherá de } \\
\text { amor para que bebas nela seu } \\
\text { contentamento. }\end{array}$ & $\begin{array}{l}\text { Sua boca, que ainda não provaste, } \\
\text { Jandira a encherá de amor para que } \\
\text { nela bebas seu contentamento. }\end{array}$ \\
\hline $\begin{array}{l}\text { "Um calção de pindoba", } \\
\text { Gregório de Matos }\end{array}$ & De Paiaiá virou-se em Abaeté. & de arecuná se tornou em abaité. \\
\hline
\end{tabular}




\section{Substituição - Pontuação}

\begin{tabular}{|c|c|c|}
\hline Título da obra/ Autor & Edição A & Edição B \\
\hline \multirow{8}{*}{$\begin{array}{l}\text { Noite da Taverna, Álvares de } \\
\text { Azevedo }\end{array}$} & $\begin{array}{l}\text { A nós frontes queimadas } \\
\text { pelo mormaço do sol da } \\
\text { vida, a nós sobre cuja } \\
\text { cabeça a velhice regelou } \\
\text { os cabelos, essas crenças }\end{array}$ & $\begin{array}{l}\text { A nós frontes queimadas pelo } \\
\text { mormaço do sol da vida, a nós sobre } \\
\text { cuja cabeça a velhice regelou os } \\
\text { cabelos, essas crianças frias! }\end{array}$ \\
\hline & $\begin{array}{l}\text { A nós os sonhos do } \\
\text { espiritualismo. }\end{array}$ & A nós os sonhos do espiritualismo! \\
\hline & $\begin{array}{l}\text { - Blasfêmia! e não crês } \\
\text { em mais nada! }\end{array}$ & $\begin{array}{l}\text { - Blasfêmia - e não crês em mais } \\
\text { nada: }\end{array}$ \\
\hline & $\begin{array}{l}\text { o filho das coxas de um } \\
\text { deus e do amor de uma }\end{array}$ & $\begin{array}{l}\text { o filho das coxas de um deus e do } \\
\text { amor de uma mulher, }\end{array}$ \\
\hline & $\begin{array}{l}\text { e que nós chamamos } \\
\text { melhor pelo seu nome - }\end{array}$ & $\begin{array}{l}\text { e que nós chamamos melhor pelo } \\
\text { seu nome - o vinho. }\end{array}$ \\
\hline & $\begin{array}{l}\text { Abaixou-se junto dele, } \\
\text { depôs a lâmpada no chão. }\end{array}$ & $\begin{array}{l}\text { Abaixou-se junto dele: depôs a } \\
\text { lâmpada no chão. }\end{array}$ \\
\hline & $\begin{array}{l}\text { Tremia; e ao segurar na } \\
\text { lanterna ressoou-lhe na } \\
\text { mão um ferro... }\end{array}$ & $\begin{array}{l}\text { Tremia, e ao segurar na lanterna } \\
\text { ressoou-lhe na mão um ferro... }\end{array}$ \\
\hline & $\begin{array}{l}\text { Viu que tinha as mãos } \\
\text { vermelhas, enxugou-as } \\
\text { nos longos cabelos de } \\
\text { Johann... }\end{array}$ & $\begin{array}{l}\text { Viu que tinha as mãos vermelhas - } \\
\text { enxugou-as nos longos cabelos de } \\
\text { Johann... }\end{array}$ \\
\hline \multirow{10}{*}{$\begin{array}{l}\text { "Um calção de pindoba a meia } \\
\text { porra", Gregório de Matos }\end{array}$} & $\begin{array}{l}\text { Não sei como acabou, } \\
\text { nem em que guerra; }\end{array}$ & $\begin{array}{l}\text { Não sei, onde acabou, ou em que } \\
\text { guerra, }\end{array}$ \\
\hline & $\begin{array}{l}\text { Onde na praia em flor o } \\
\text { mar suspira... }\end{array}$ & $\begin{array}{l}\text { Onde na praia em flor o mar } \\
\text { suspira, }\end{array}$ \\
\hline & $\begin{array}{l}\text { E mais poesia o arrebol } \\
\text { transpira... }\end{array}$ & Mais poesia do arrebol transpira; \\
\hline & $\begin{array}{l}\text { Errando à noite, a } \\
\text { lamentosa turma... }\end{array}$ & Errando à noite, a lamentosa turma; \\
\hline & $\begin{array}{l}\text { E de amorosos prantos } \\
\text { perfumá-la... }\end{array}$ & E de amorosos prantos perfumá-la, \\
\hline & Desbotada coroa do & Desbotada coroa do poeta, \\
\hline & $\begin{array}{l}\text { Foi ela mesma quem } \\
\text { prendeu-te flores! }\end{array}$ & $\begin{array}{l}\text { Foi ela mesma quem prendeu-te } \\
\text { flores... }\end{array}$ \\
\hline & $\begin{array}{l}\text { Inda virgem do alento } \\
\text { dos amores!... }\end{array}$ & Inda virgem do alento dos amores... \\
\hline & $\begin{array}{l}\text { Ai! que tudo passou!... } \\
\text { só resta agora }\end{array}$ & $\begin{array}{l}\text { Ah! que tudo passou! - só tenho } \\
\text { agora }\end{array}$ \\
\hline & $\begin{array}{l}\text { Com ela sonharei } \\
\text { eternamente... }\end{array}$ & Com ela sonharei eternamente, \\
\hline \multirow[t]{5}{*}{$\begin{array}{l}\text { Virgem morta, Álvares de } \\
\text { Azevedo }\end{array}$} & $\begin{array}{l}\text { Lábio de } \quad \text { morte } \\
\text { murmurou: - É tarde! }\end{array}$ & $\begin{array}{l}\text { Lábio de morte murmurou - É } \\
\text { tarde! }\end{array}$ \\
\hline & $\begin{array}{l}\text { Sentir-me abandonado } \mathrm{e} \\
\text { moribundo!?... }\end{array}$ & $\begin{array}{lll}\text { Sentir-me } & \text { abandonado } & \text { e } \\
\text { moribundo! } & \end{array}$ \\
\hline & $\begin{array}{l}\text { Das minhas noites a visão } \\
\text { perdida... }\end{array}$ & Das minhas noites a visão perdida! \\
\hline & $\begin{array}{l}\text { E quando a mágoa } \\
\text { devorar meu peito... }\end{array}$ & $\begin{array}{l}\text { E quando a mágoa devorar meu } \\
\text { peito, }\end{array}$ \\
\hline & $\begin{array}{l}\text { E quando eu morra de } \\
\text { esperar por ela... }\end{array}$ & $\begin{array}{l}\text { E quando eu morra de esperar por } \\
\text { ela, }\end{array}$ \\
\hline \multirow{5}{*}{ "A Mulata", Melo Morais Filho } & Quaes muitas brancas & Quaes muitas brancas não são! \\
\hline & Tenho requebros mais & Tenho requebros mais bellos; \\
\hline & Demoro os olhares & Demoro os olhares meus; \\
\hline & $\begin{array}{l}\text { Que tentação... } \\
\text { maldicta... }\end{array}$ & Mas, se murmuram: “maldita! \\
\hline & Sei encontral-o no amor. & Sei encontral-o no amor; \\
\hline
\end{tabular}


122 MOREIRA, Camila de Paula; FORSTER, Larissa Gonçalves et al.

\section{Substituição - Palavras}

\begin{tabular}{|c|c|c|}
\hline Título da obra/ Autor & Edição A & Edição B \\
\hline \multirow{4}{*}{$\begin{array}{c}\text { Noite da taverna, Álvares de } \\
\text { Azevedo }\end{array}$} & $\begin{array}{l}\text { A nós frontes queimadas } \\
\text { pelo mormaço do sol da } \\
\text { vida, a nós sobre cuja } \\
\text { cabeça a velhice regelou } \\
\text { os cabelos, essas crenças }\end{array}$ & $\begin{array}{l}\text { A nós frontes queimadas pelo } \\
\text { mormaço do sol da vida, a nós sobre } \\
\text { cuja cabeça a velhice regelou os } \\
\text { cabelos, essas crianças frias! }\end{array}$ \\
\hline & $\begin{array}{l}\text { E pois ergamo-nos, nós } \\
\text { que amarelecemos nas } \\
\text { noites desbotadas de } \\
\text { estudo insano, e vimos } \\
\text { que a ciência é falsa e } \\
\text { esquiva, que ela mente e } \\
\text { embriaga como um beijo }\end{array}$ & $\begin{array}{l}\text { E pois ergamo-nos, nós que } \\
\text { amanhecemos nas noites } \\
\text { desbotadas de estudo insano, e } \\
\text { vimos que a ciência é falsa e esquiva, } \\
\text { que ela mente e embriaga como um } \\
\text { beijo de mulher. }\end{array}$ \\
\hline & $\begin{array}{l}\text { - Quero que todos se } \\
\text { levantem, e com a cabeça } \\
\text { descoberta clamem: Ao } \\
\text { deus Pã da natureza, } \\
\text { àquele que a antiguidade } \\
\text { chamou Baco - o filho } \\
\text { das coxas de um deus e }\end{array}$ & $\begin{array}{l}\text { - Quero que todos se levantem, e } \\
\text { com a cabeça descoberta digam-no: } \\
\text { Ao Deus Pan da natureza, àquele que } \\
\text { a antiguidade chamou Baco o filho } \\
\text { das coxas de um deus e do amor de } \\
\text { uma mulher, }\end{array}$ \\
\hline & $\begin{array}{l}\text { A fronte da mulher } \\
\text { pendeu e sua mão } \\
\text { pousou na garganta dele. }\end{array}$ & $\begin{array}{l}\text { A fronte da mulher pendeu - e sua } \\
\text { mão passou na garganta dele. }\end{array}$ \\
\hline \multirow{7}{*}{$\begin{array}{l}\text { "Um calção de pindoba a meia } \\
\text { porra", Gregório de Matos }\end{array}$} & $\begin{array}{l}\text { Um calção de pindoba a } \\
\text { meia porra, }\end{array}$ & Um calção de pindoba a meia zorra \\
\hline & $\begin{array}{l}\text { o pai, que lho envazou } \\
\text { com ũa titara, }\end{array}$ & O pai, que lho envazou cuma titara, \\
\hline & Alarve sem razão, bruto & Animal sem razão, bruto sem fé, \\
\hline & $\begin{array}{l}\text { sem mais lei que a do } \\
\text { gosto, quando berra, }\end{array}$ & $\begin{array}{l}\text { Sem mais Leis, que as do gosto, } \\
\text { quando erra, }\end{array}$ \\
\hline & $\begin{array}{l}\text { de arecuná se tornou em } \\
\text { abaité. }\end{array}$ & De Paiaiá virou-se em Abaeté. \\
\hline & $\begin{array}{l}\text { Não sei como acabou, } \\
\text { nem em que guerra; }\end{array}$ & $\begin{array}{l}\text { Não sei, onde acabou, ou em que } \\
\text { guerra, }\end{array}$ \\
\hline & $\begin{array}{l}\text { só sei que do Adão de } \\
\text { Marapé }\end{array}$ & Só sei, que deste Adão de Massapé, \\
\hline \multirow{3}{*}{$\begin{array}{c}\text { Virgem morta, Álvares de } \\
\text { Azevedo }\end{array}$} & $\begin{array}{l}\text { Lá onde geme a brisa do } \\
\text { crepúsculo }\end{array}$ & $\begin{array}{l}\text { E, quando geme a brisa do } \\
\text { crepúsculo, }\end{array}$ \\
\hline & $\begin{array}{l}\text { Deitem o corpo da } \\
\text { beleza morta. }\end{array}$ & Manso repousem a beleza morta. \\
\hline & $\begin{array}{l}\text { E, entre cânticos de } \\
\text { amor e de saudade, }\end{array}$ & Nos cânticos de amor e de saudade \\
\hline \multirow{3}{*}{ "A Mulata", Melo Morais Filho } & $\begin{array}{lll}\text { Que } & \text { tentação... } & \text { que } \\
\end{array}$ & Mas, se murmuram: maldita! \\
\hline & $\begin{array}{l}\text { - Ai! mulata! ai! } \\
\text { borboleta! / É tua sina }\end{array}$ & $\begin{array}{l}\text { Minh'alma é qual borboleta, / Que } \\
\text { vôa e vôa inquieta }\end{array}$ \\
\hline & $\begin{array}{l}\text { Tu pousas de floôr em } \\
\text { flôr. }\end{array}$ & Pousando de flor em flor. \\
\hline \multirow{5}{*}{ Ubirajara, José de Alencar } & $\begin{array}{l}\text { Os veados saltam das } \\
\text { moitas de ubaia e vêm } \\
\text { retouçar na grama, }\end{array}$ & $\begin{array}{l}\text { Ora veados saltam das moitas de } \\
\text { ubaia e vêm retouçar na grama, } \\
\text { zombando do caçador. }\end{array}$ \\
\hline & $\begin{array}{l}\text { quando começou a dança } \\
\text { guerreira que durou até } \\
\text { perto da alvorada. }\end{array}$ & $\begin{array}{l}\text { quando começou a dança guerreira } \\
\text { que durou até o romper da alvorada. }\end{array}$ \\
\hline & $\begin{array}{l}\text { A virgem araguaia } \\
\text { acreditava ter dormido a } \\
\text { última noite na cabana } \\
\text { paterna, }\end{array}$ & $\begin{array}{l}\text { A virgem tocantim acreditava ter } \\
\text { dormido a última noite na cabana } \\
\text { paterna, }\end{array}$ \\
\hline & Arpão de ouro, arpão & arpões de outro arpão vencido: \\
\hline & Cego, turbado, e corrido, & cego, turbado, e sentido, \\
\hline
\end{tabular}


ANEXO 2: Tabela com nomes dos alunos do curso de Filologia Portuguesa que realizaram o trabalho de cotejo entre os testemunhos da mesma obra. Na primeira coluna, seguem os nomes; na segunda o título da obra e do autor; nas terceira e quarta, localização, editora, ano e página do trecho selecionado.

\begin{tabular}{|c|c|c|c|}
\hline Alunos & Título da obra & Edição $\mathbf{A}$ & Edição B \\
\hline $\begin{array}{l}\text { Camila de Paula } \\
\text { Moreira }\end{array}$ & $\begin{array}{l}\text { A mão e a luva, } \\
\text { Machado de Assis }\end{array}$ & $\begin{array}{c}\text { Rio de Janeiro/São } \\
\text { Paulo/Porto Alegre: W. M. } \\
\text { Jacson Inc. Editores, 1946, } \\
\text { p. } 13\end{array}$ & $\begin{array}{l}\text { São Paulo: Editora } \\
\text { Ática, 1981, p.12 }\end{array}$ \\
\hline $\begin{array}{l}\text { Camila Pinheiro da } \\
\text { Cruz }\end{array}$ & Iracema, José de Alencar & $\begin{array}{l}\text { Rio de Janeiro: Livraria } \\
\text { Antunes, 1932, p. 76-77 }\end{array}$ & $\begin{array}{c}\text { Barcelona: Editorial Sol } \\
90,2004, \text { p. } 80-81\end{array}$ \\
\hline $\begin{array}{l}\text { Caroline Florencio da } \\
\text { Silva }\end{array}$ & Senhora, José de Alencar & $\begin{array}{c}\text { Sem localização: Moderna, } \\
1983\end{array}$ & $\begin{array}{c}\text { Sem localização: } \\
\text { Melhoramentos, Sem } \\
\text { data }\end{array}$ \\
\hline $\begin{array}{l}\text { Dalila Gonçalves } \\
\text { Luiz }\end{array}$ & $\begin{array}{c}\text { "Um Sanção de } \\
\text { caramelo", Gregório de } \\
\text { Matos }\end{array}$ & $\begin{array}{c}\text { Sem localização: Record, } \\
1990\end{array}$ & $\begin{array}{c}\text { Sem localização: } \\
\text { Global, } 2000\end{array}$ \\
\hline $\begin{array}{c}\text { Daniele Gomes } \\
\text { Santos }\end{array}$ & $\begin{array}{c}\text { Dom Casmurro, } \\
\text { Machado de Assis }\end{array}$ & $\begin{array}{c}\text { São Paulo: Cárculo do } \\
\text { Livro, Sem data }\end{array}$ & São Paulo: Klick, 1997 \\
\hline Elen Pereira Gomes & $\begin{array}{l}\text { "Dentes negros e } \\
\text { cabelos azuis", Lima } \\
\text { Barreto }\end{array}$ & $\begin{array}{l}\text { Histórias e Sonhos. São } \\
\text { Paulo: Brasiliense, 1956, p. } \\
222\end{array}$ & $\begin{array}{c}\text { Contos Reunidos. Belo } \\
\text { Horizonte: Crisálida, } \\
\text { 2005, p. } 345\end{array}$ \\
\hline $\begin{array}{c}\text { Evelise Mateos } \\
\text { Nicoletti }\end{array}$ & Iracema, José de Alencar & $\begin{array}{c}\text { São Paulo: Editora Atica, } \\
1989\end{array}$ & $\begin{array}{l}\text { São Paulo: Ciranda } \\
\text { Cultural, } 2006\end{array}$ \\
\hline $\begin{array}{l}\text { Gabriel Madeira } \\
\text { Fernandes }\end{array}$ & $\begin{array}{l}\text { "A cada canto um } \\
\text { grande conselheiro", } \\
\text { Gregório de Matos }\end{array}$ & $\begin{array}{l}\text { Gregório de Matos: obra } \\
\text { poética. Rio de Janeiro: } \\
\text { Record, 1990, p. } 33\end{array}$ & $\begin{array}{l}\text { Poemas Escolbidos.São } \\
\text { Paulo: Gírculo do } \\
\text { Livro, Sem data, p. } 31 \\
\end{array}$ \\
\hline $\begin{array}{c}\text { Ileana Celeste } \\
\text { Fernández Franzoso }\end{array}$ & $\begin{array}{l}\text { "A uns olhos se viu } \\
\text { rendido", Gregório de } \\
\text { Matos }\end{array}$ & $\begin{array}{l}\text { Obras de Gregório de Matos, II } \\
\text { - Lyrica. Publicações da } \\
\text { Academia Brasileira, } \\
\text { Typographia do Annuario } \\
\text { do Brasil, } 1923\end{array}$ & $\begin{array}{c}\text { Melhores Poemas / } \\
\text { Gregório de Matos. São } \\
\text { Paulo: Global Editora, } \\
2000\end{array}$ \\
\hline Ludmila De Nardi & $\begin{array}{c}\text { "Um calção de pindoba } \\
\text { a meia porra" de } \\
\text { Gregório de Matos }\end{array}$ & $\begin{array}{c}\text { Gregório de Matos - } \\
\text { Literatura Comentada. São } \\
\text { Paulo: Abril Educação, } \\
1981\end{array}$ & $\begin{array}{l}\text { Os melhores poemas de } \\
\text { Gregório de Matos. } \\
\text { Global, } 2001\end{array}$ \\
\hline $\begin{array}{c}\text { Ludmila Rodrigues } \\
\text { Silva }\end{array}$ & $\begin{array}{c}\text { Ubirajara, José de } \\
\text { Alencar }\end{array}$ & $\begin{array}{c}\text { Porto Alegre: L\&PM } \\
\text { Pocket, 2001 } \\
\end{array}$ & $\begin{array}{c}\text { São Paulo: Edições } \\
\text { Melhoramentos, } 1958\end{array}$ \\
\hline Michele Kaori Yogui & $\begin{array}{l}\text { "Virgem morta", } \\
\text { Álvares de Azevedo }\end{array}$ & $\begin{array}{c}\text { Lira dos Vinte Anos. São } \\
\text { Paulo: Martins Fontes, } \\
1996\end{array}$ & $\begin{array}{l}\text { Álvares de Azevedo: } \\
\text { Poesias Completas. } \\
\text { Campinas: Editora da } \\
\text { Unicamp, } 2002 \\
\end{array}$ \\
\hline $\begin{array}{l}\text { Paula Souza Dias } \\
\text { Nogueira }\end{array}$ & Iracema, José de Alencar & $\begin{array}{l}\text { São Paulo: Editora } \\
\text { Moderna, } 1984\end{array}$ & $\begin{array}{c}\text { Sem localização: } \\
\text { Melhoramentos, Sem } \\
\text { data }\end{array}$ \\
\hline $\begin{array}{c}\text { Renata Fevereiro } \\
\text { Berenguer }\end{array}$ & $\begin{array}{c}\begin{array}{c}\text { Noite na taverna, Álvares } \\
\text { de Azevedo }\end{array} \\
\end{array}$ & $\begin{array}{c}\text { Editora Francisco Alves, } \\
1988, \text { p. 63-64,132 } \\
\end{array}$ & $\begin{array}{c}\text { Princípio, } 1994, \text { p. 10- } \\
12,90\end{array}$ \\
\hline $\begin{array}{l}\text { Sandra Ramos } \\
\text { Casemiro }\end{array}$ & $\begin{array}{l}\text { "A Mulata", Melo } \\
\text { Morais Filho }\end{array}$ & $\begin{array}{c}\text { Mythos e poemas. Rio de } \\
\text { Janeiro: Typographia de G. } \\
\text { Leuzinger \& Filhos, 1884, } \\
\text { p. } 85-89\end{array}$ & $\begin{array}{l}\text { Cantos do Equador. Rio } \\
\text { de Janeiro: H. Garnier, } \\
\text { 1900, p. } 71-74\end{array}$ \\
\hline
\end{tabular}

